\title{
Aquatic food webs in mangrove and seagrass habitats of Centla Wetland, a Biosphere Reserve in Southeastern Mexico
}

\author{
Manuel Mendoza-Carranza ${ }^{1}$, David J. Hoeinghaus ${ }^{2}$, Alexandre M. Garcia ${ }^{3}$ \\ and Ángel Romero-Rodriguez ${ }^{1}$
}

Mangrove and seagrass habitats are important components of tropical coastal zones worldwide, and are conspicuous habitats of Centla Wetland Biosphere Reserve (CWBR) in Tabasco, Mexico. In this study, we examine food webs in mangrove- and seagrass-dominated habitats of CWBR using stable isotope ratios of carbon and nitrogen. Our objective was to identify the importance of carbon derived from mangroves and seagrasses to secondary production of aquatic consumers in this poorly studied conservation area. Carbon and nitrogen isotope ratios of basal sources and aquatic consumers indicated that the species-rich food webs of both habitats are dependent on riparian production sources. The abundant Red mangrove Rhizophora mangle appears to be a primary source of carbon for the mangrove creek food web. Even though dense seagrass beds were ubiquitous, most consumers in the lagoon food web appeared to rely on carbon derived from riparian vegetation (e.g. Phragmites australis). The introduced Amazon sailfin catfish Pterygoplichthys pardalis had isotope signatures overlapping with native species (including high-value fisheries species), suggesting potential competition for resources. Future research should examine the role played by terrestrial insects in linking riparian and aquatic food webs, and impacts of the expanding $P$. pardalis population on ecosystem function and fisheries in CWBR. Our findings can be used as a baseline to reinforce the conservation and management of this important reserve in the face of diverse external and internal human impacts.

Manguezais e pradarias de gramíneas são importantes componentes das zonas costeiras tropicais em todo o mundo, sendo habitats comuns nos "Pântanos de Centla", uma Reserva da Biosfera localizada em Tabasco, México. Nesse trabalho, são investigadas as teias alimentares de habitats dominados por manguezais e pradarias de gramíneas, através de isótopos estáveis de carbono e nitrogênio, tendo como objetivo identificar a importância do carbono derivado desses produtores para a produção aquática secundária nessa unidade de conservação tão pouco estudada. As razões isotópicas de carbono e nitrogênio das fontes basais e dos consumidores aquáticos indicam que as teias alimentares, ricas em espécies, de ambos os habitats, são dependentes da produção ripária. O abundante mangue-vermelho Rhizophora mangle parece ser a fonte primária de carbono no habitat dominado por manguezais. Em contraste, muito embora as pradarias de gramíneas sejam conspícuas no ambiente lagunar estudado, muitos dos consumidores da teia alimentar nessa região parecem depender do carbono oriundo da vegetação ripária (e.g. Phragmites australis). A espécie de bagre exótica Pterygoplichthys pardalis possui assinaturas isotópicas que se sobrepõem a das espécies nativas (incluindo algumas de elevado valor comercial na pesca), sugerindo competição potencial por recursos. Novas investigações deveriam avaliar o papel dos insetos terrestres como elo de conexão entre as teias alimentares da mata ripária e do ambiente aquático, bem como os impactos da expansão da população de $P$. pardalis sobre o funcionamento do ecossistema e das pescarias no "Pântano de Centla". Considerando os múltiplos impactos antrópicos na região, os resultados obtidos no presente trabalho podem ser utilizados como uma base de referência em programas de gerenciamento e conservação da diversidade nessa importante Reserva da Biosfera.

Key words: Carbon flow, Food chains, Neotropical, Rizophora mangle, Submerged aquatic vegetation, Vallisneria americana.

${ }^{1}$ El Colegio de la Frontera Sur Unidad Villahermosa. Km 15.5 s/n Carr. a Reforma, Rancheria Guineo 2a, 86280 Villahermosa, Tabasco, Mexico.mcarranza@ecosur.mx (MMC)

${ }^{2}$ Department of Biological Sciences, Institute of Applied Science, University of North Texas, 1155 Union Circle \#310559, Denton, Texas 76203-5017, USA.

${ }^{3}$ Instituto de Oceanografia, Universidade Federal do Rio Grande - FURG. CP 474, 96201-900 Rio Grande, RS, Brazil. 


\section{Introduction}

Mangroves are an important vegetation type fringing tropical continental margins (Hogarth, 2007). They are highly productive, varying according to species composition, soil salinity, degree of tidal inundation, nutrient availability and photosynthetic capacity (Nichols et al., 1985; Sobrado, 1999; Sobrado \& Ball, 1999). Mangrove ecosystems are recognized as important nursery and feeding habitats for a great diversity of invertebrate and fish species (Nagelkerken \& Velde, 2004a). At the same time, dense seagrass beds are often present in adjacent estuarine and marine habitats and are known to carry out an array of ecological functions (Vermaat et al., 2000; Moore, 2004) including as refuge or feeding sites for commercially and ecologically important fish species (Thayer et al., 1975; Richardson et al., 1998; Heck et al., 2003; Melville \& Connolly, 2003; Sheridan \& Hays, 2003).

Previous research indicates that carbon derived from mangroves is often less important as an energy source for aquatic consumers, primarily fishes, than that derived from nearby marine seagrass ecosystems (Rodelli et al., 1984; Bouillon et al., 2002; Sheridan \& Hays, 2003; Nagelkerken \& Velde, 2004a, 2004b). Most previous studies are from large and open mangrove ecosystems with high connectivity with other marine and coastal areas. In smaller tidal creeks or restricted lagoons, aquatic consumers may be expected to rely more heavily on carbon derived in situ due to potentially lower connectivity with other ecosystem types. For example, aquatic consumers in isolated mangrove creeks may be expected to rely more heavily on mangrove-derived carbon than aquatic consumers in mangrove habitats with high connectivity to seagrass beds.

Both mangrove creeks and seagrass beds are conspicuous habitats of the Centla Wetland Biosphere Reserve (CWBR) in Tabasco, Mexico. Although this complex wetland ecosystem has been identified as an area of conservation concern, little research has been conducted on aquatic food webs within the reserve. In this study, we examine food webs in mangroves and seagrasses dominated habitats of CWBR using stable isotope ratios of carbon and nitrogen. Our primary objective was to identify the importance of carbon derived from mangroves and seagrasses to secondary production of aquatic consumers. Understanding the linkages among consumers and carbon sources supporting secondary production is important for conservation and management of aquatic species and fisheries resources, and our findings have direct application to management and conservation of this poorly-studied Biosphere Reserve.

\section{Material and Methods}

\section{Study sites}

The CWBR is located under the influence of the largest rivers in Mexico, the Grijalva and Usumacinta, which together have a drainage basin containing $28 \%$ of all the surface water in Mexico. The basin is second to the Mississippi River basin in freshwater contribution to the Gulf of Mexico, and seventh in discharge worldwide (Yáñez-Arancibia \& Sánchez-Gil, 1988; Arriaga et al., 1998; INE, 2000). Based on the exceptional biological and ecological features of this area, it was declared a Biosphere Reserve by the federal government of Mexico in 1992 and subscribed in the RAMSAR convention of 1995 as a wetland area of international importance.

Field collections were conducted at two sampling sites: Polo Stream and San Pedrito Lagoon (Fig. 1). Polo Stream is a semi-enclosed mangrove creek located $15 \mathrm{~km}$ above the Grijalva River mouth $\left(18^{\circ} 29^{\prime} 21^{\prime \prime} \mathrm{N} 92^{\circ} 38^{\prime} 23^{\prime \prime} \mathrm{W}\right)$. The stream is $2.6 \mathrm{~km}$ long, with an average depth of $2 \mathrm{~m}$ and average width of $15 \mathrm{~m}$. The creek has a sandy substrate with a high proportion of organic matter. Five tree species are found in mangrove community along the margins of Polo Stream, dominated by the Red mangrove (Rizophora mangle; Novelo, 2006). In contrast, San Pedrito Lagoon has a surface area of $136 \mathrm{~km}^{2}$, an average depth of $1.5 \mathrm{~m}$ and is located $26 \mathrm{~km}$ above the Grijalva River mouth (18²0’36”N 92'33'50”W). Two narrow channels situated in its northwest sector connect this lagoon to the Usumacinta River. The most representative beds of the American eelgrass $V$. americana $\left(1.78 \mathrm{~km}^{2}\right.$ and $\left.0.36 \mathrm{~km}^{2}\right)$ found inside Centla Reserve are located near these channels and in the central portion of the lagoon. The riparian vegetation is dominated by Common reed (Phragmites australis) and sparse patches of Thalia geniculata (Novelo, 2006).

\section{Field collection, sample processing and analyses}

Intensive field surveys were conducted at each sampling site during two days in June 2006 to collect representative components of the food webs for analyses of carbon and nitrogen stable isotope ratios. Leaves from mangroves and floating, emergent and submerged macrophytes were collected by hand. Fishes were collected using multiple gears (beach seine, cast nets, gillnet and beam trawl) to collect representative samples of the fish diversity at each site. Bivalves (Lampsilis tampicoensis, Polymesoda arctata), gastropods (Neritina reclivata and Pomacea flagellata) and crabs were collected primarily by hand but also inadvertently while sampling fishes.

All samples were placed on ice for transport to the laboratory and stored frozen. Samples for isotopic analysis consisted of several leaves of each plant species, and approximately $5 \mathrm{~g}$ fresh weight of dorsal muscle tissue from individual fish or, in the case of the smallest size-classes $(<30$ $\mathrm{mm}$ total length), a composite sample of individuals of approximately the same size was taken by combining pure muscle tissue from multiple individuals from the same site (Garcia et al., 2007). We removed the abdominal muscle of individual adult crustaceans, but in the case of smaller specimens we obtained a composite muscle sample of individuals of approximately the same size (Hoeinghaus \& Davis, 2007). For bivalves and gastropods, the foot muscle of multiple individuals from each location was removed and processed for analysis in the same manner as for fish and crustacean samples (Hoeinghaus et al., 2007). Thawed samples 


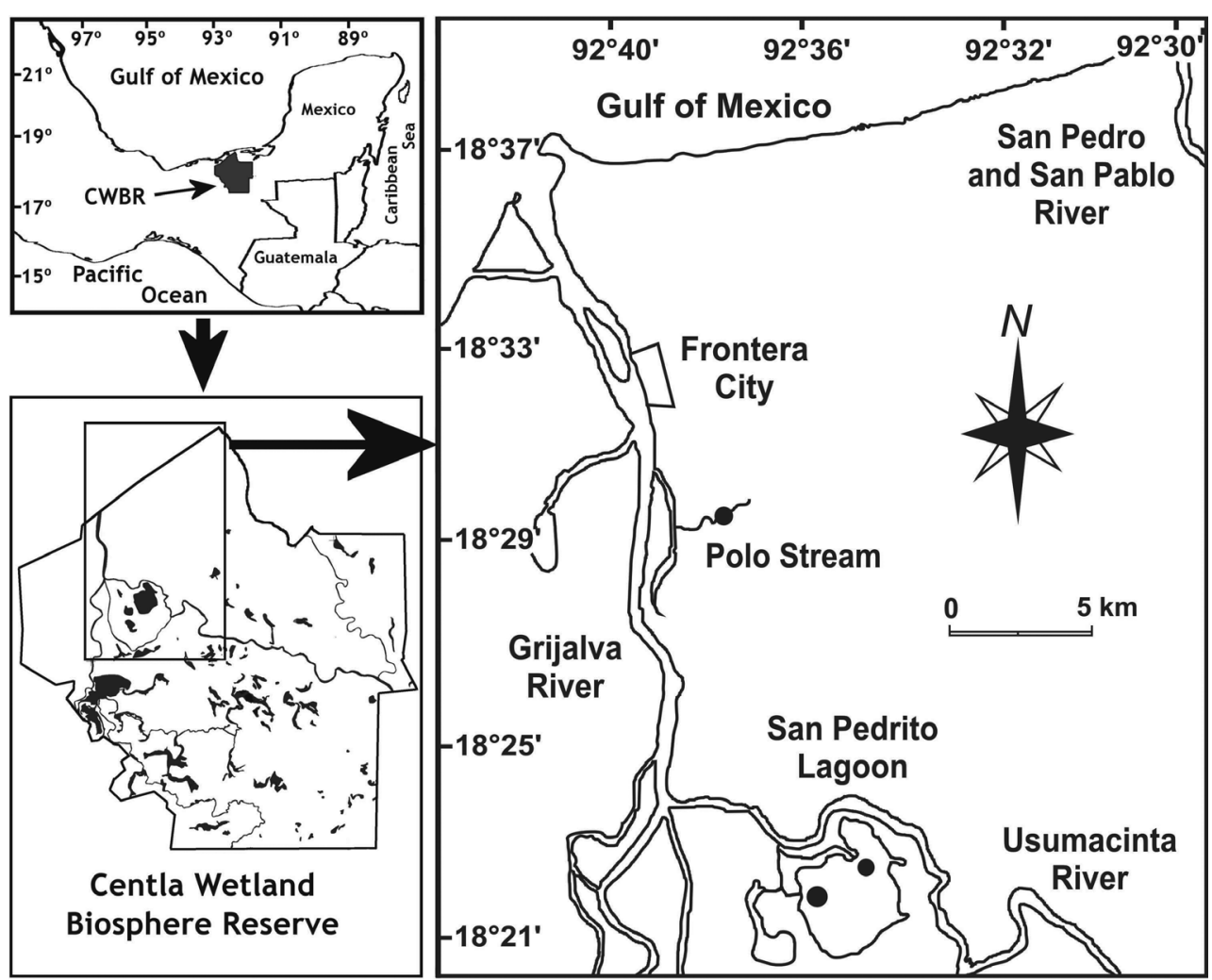

Fig. 1. Map depicting the location and extent of Centla Wetland Biosphere Reserve (CWBR) in Southern Mexico. The detailed study area map illustrates locations of field collections at Polo Stream and San Pedrito Lagoon along the Grijalva and Usumacinta Rivers in Tabasco, Mexico.

were inspected to remove non-muscle matter (bone or scales in fish tissue or calcareous parts in crustaceans or bivalves), rinsed with distilled water, placed in sterile Petri dishes, and dried in an oven at $60^{\circ} \mathrm{C}$ to constant weight (minimum of 48 hrs). Dried samples were ground to a fine powder with a mortar and pestle and stored in clean glass vials. Sub-samples were weighed to the nearest $0.01 \mathrm{mg}$, pressed into Ultra-Pure tin capsules (Costech, Valencia, CA), and sent to the Analytical Chemistry Laboratory, Institute of Ecology at the University of Georgia for determination of stable isotope ratios $\left({ }^{13} \mathrm{C} /{ }^{12} \mathrm{C}\right.$ and ${ }^{15} \mathrm{~N} /{ }^{14} \mathrm{~N}$ ).

Results are expressed in delta notation (parts per thousand deviation from a standard material): $\delta^{13} \mathrm{C}$ or $\delta^{15} \mathrm{~N}=$ $\left[\left(\mathrm{R}_{\text {sample }} / \mathrm{R}_{\text {standard }}\right)-1\right]$. 1000; where $\mathrm{R}={ }^{13} \mathrm{C} /{ }^{12} \mathrm{C}$ or ${ }^{15} \mathrm{~N} /{ }^{14} \mathrm{~N}$. The standard material for carbon is Pee Dee Belemnite (PDB) limestone, and the nitrogen standard is atmospheric nitrogen. Bi-plots of $\delta^{15} \mathrm{~N}$ and $\delta^{13} \mathrm{C}$ values of fishes and macroinvertebrates were used to visualize patterns of isotopic variation across sites. Individuals of some large-bodied fish species were separated into size classes to reduce potential bias due to ontogenetic diet shifts. Because carbon isotope signatures of dietary items are conserved within $1 \%$ in consumer tissues (McCutchan et al., 2003), the relative importance of various sources of organic carbon assimilated by consumers is indexed by relative positions of consumers on the $\mathrm{x}$-axis ( $\delta^{13} \mathrm{C}$ values). Nitrogen isotope values of consumers are typically enriched 2.5-3.4\%o relative to their diet (Post, 2002; Vanderklift \& Ponsard, 2003), and therefore $\delta^{15} \mathrm{~N}$ is useful as an indicator of trophic position in addition to refining source contribution estimates based on $\delta^{13} \mathrm{C}$ values (Peterson \& Fry, 1987).

\section{Results}

Vegetation at Polo Stream was dominated by five tree species, most notably the Red mangrove Rizophora mangle (Table 1). These mangrove species had $\delta^{13} \mathrm{C}$ values between 29.91 and $-26.29 \%$, similar to carbon isotope signatures observed for the riparian vegetation at San Pedrito Lagoon (e.g. Phragmites australis, Thalia geniculata and Typha latifolia; Table 1, Fig. 2). Although carbon isotope signatures were similar across the tree species found at the mangrove creek, values of $\delta^{15} \mathrm{~N}$ were highly variable among species, ranging from $3.07 \%$ for the Black mangrove Avicennia germinalis to $8.10 \%$ for the White mangrove Laguncularia racemosa (Table 1, Fig. 2). Water hyacinth Eichhornia crassipes was present at both Polo Stream and San Pedrito Lagoon (with similar $\delta^{13} \mathrm{C}$ values), but seagrass was completely absent at Polo Stream (Table 1). In contrast with Polo Stream, the most conspicuous primary producer at San Pedrito Lagoon is American eelgrass Vallisneria americana, which forms dense beds in the lagoon. Epiphytic algae is also abundant in the lagoon, using the eelgrass as a common substrate. 
Table 1. Sample size (n) and mean $\delta^{13} \mathrm{C}$ and $\delta^{15} \mathrm{~N}$ values $( \pm \mathrm{SD})$ of primary producers and secondary consumers collected at Polo Stream and San Pedrito Lagoon. Mean total length ( $\mathrm{mm} \mathrm{TL} \pm \mathrm{SD})$ is provided for fishes, crustaceans and mollusks. Asterisks $(*)$ designate composite samples (see Methods), and the number of asterisks indicates the number of composite samples.

\begin{tabular}{|c|c|c|c|c|c|c|c|c|}
\hline \multirow{2}{*}{ Species } & \multicolumn{4}{|c|}{ Polo Stream } & \multicolumn{4}{|c|}{ San Pedrito Lagoon } \\
\hline & $\mathrm{n}$ & mm TL $( \pm \mathrm{SD})$ & $\delta^{13} \mathrm{C}( \pm \mathrm{SD})$ & $\delta^{15} \mathrm{~N}( \pm \mathrm{SD})$ & $\mathrm{n}$ & $\mathrm{mm}$ TL $( \pm \mathrm{SD})$ & $\delta^{13} \mathrm{C}( \pm \mathrm{SD})$ & $\delta^{15} \mathrm{~N}( \pm \mathrm{SD})$ \\
\hline \multicolumn{9}{|l|}{ Fishes } \\
\hline Anchoa mitchilli & 3 & $42.33(3.06)$ & $-28.71(1.52)$ & $10.03(0.21)$ & & & & \\
\hline Astyanax aeneus & 6 & $57.50(13.85)$ & $-26.13(0.77)$ & $6.80(0.57)$ & 3 & $43.67(5.03)$ & $-28.36(0.89)$ & $8.86(0.10)$ \\
\hline Atherinella alvarezi & 1 & 73.00 & -31.82 & 5.39 & & & & \\
\hline Atherinella alvarezi & 4* & $37.25(1.71)$ & -27.51 & 7.31 & & & & \\
\hline Atractosteus tropicus & 3 & $301.00(13.53)$ & $-27.63(2.23)$ & $10.16(0.55)$ & 1 & 361.00 & -27.17 & 7.99 \\
\hline Batrachoides goldmani & & & & & 1 & 115.00 & -28.36 & 7.41 \\
\hline Batrachoides goldmani & & & & & 1 & 193.00 & -26.59 & 10.26 \\
\hline Centropomus undecimalis & & & & & 1 & 163.00 & -29.98 & 8.23 \\
\hline Cichlasoma salvini & 3 & $45.33(10.79)$ & $-27.99(1.02)$ & $4.10(5.75)$ & 4 & $54.00(18.92)$ & $-28.38(2.95)$ & $8.02(0.84)$ \\
\hline Cichlasoma urophthalmus & 2 & $40.50(0.71)$ & $-28.43(4.12)$ & $6.54(0.01)$ & 3 & $49.00(19.47)$ & $-27.63(0.45)$ & $6.74(0.83)$ \\
\hline Cichlasoma urophthalmus & & & & & 1 & 140.00 & -25.21 & 8.43 \\
\hline Ctenopharyngodon idella & & & & & 3 & $251.00(4.58)$ & $-22.43(3.30)$ & $7.00(1.04)$ \\
\hline Diapterus auratus & & & & & $9 * * *$ & $33.22(1.64)$ & $-28.75(2.73)$ & $7.49(3.10)$ \\
\hline Dorosoma anale & 3 & $90.76(4.93)$ & $-31.85(0.92)$ & $7.65(0.26)$ & 5 & $156.80(13.05)$ & $-28.83(1.14)$ & $5.79(5.72)$ \\
\hline Dorosoma petenense & 3 & $69.67(13.50)$ & $-29.51(2.62)$ & $4.72(2.04)$ & 3 & $41.33(3.21)$ & $-28.25(0.66)$ & $7.36(2.34)$ \\
\hline Dorosoma petenense & & & & & 2 & $138.00(8.49)$ & $-27.73(0.03)$ & $6.71(3.59)$ \\
\hline Eugerres plumieri & 1 & 53.00 & -31.50 & 8.60 & 3 & $41.00(17.35)$ & $-27.01(1.23)$ & $9.48(2.73)$ \\
\hline Gobiomorus dormitor & & & & & 1 & 150.00 & -30.37 & 8.41 \\
\hline Gobiomorus dormitor & & & & & 2 & $211.50(2.12)$ & $-27.40(0.35)$ & $8.37(0.07)$ \\
\hline Microphis brachyurus lineatus & & & & & 3 & $169.33(2.52)$ & $-28.16(4.01)$ & $9.82(1.09)$ \\
\hline Mugil cephalus & $5^{*}$ & $33.00(0.00)$ & -20.65 & 9.37 & & & & \\
\hline Oreochromis sp. & 2 & $142.00(1.41)$ & $-32.50(0.12)$ & $5.23(0.64)$ & & & & \\
\hline Parachromis friedrichsthalii & 1 & 45.00 & -29.82 & 6.25 & 2 & $123.50(26.16)$ & $-29.57(1.06)$ & $6.88(3.48)$ \\
\hline Parachromis managuensis & & & & & 1 & 111.00 & -26.72 & 8.54 \\
\hline Petenia splendida & & & & & 3 & $204.00(13.45)$ & $-26.91(1.50)$ & $7.72(3.65)$ \\
\hline Pterygoplichthys pardalis & & & & & 5 & $142.60(47.19)$ & $-29.16(1.91)$ & $7.78(1.18)$ \\
\hline Rhamdia quelen & & & & & 1 & 175.00 & -27.74 & 4.18 \\
\hline Strongylura marina & & & & & 3 & $406.67(28.36)$ & $-27.65(2.22)$ & $9.50(1.96)$ \\
\hline Thorichthys helleri & 3 & $56.00(14.53)$ & $-30.89(0.66)$ & $6.82(0.65)$ & 3 & $53.67(4.04)$ & $-28.45(0.87)$ & $7.54(0.14)$ \\
\hline Thorichthys helleri & 2 & $106.50(0.71)$ & $-28.69(1.19)$ & $8.20(0.10)$ & 3 & $101.33(9.45)$ & $-27.63(1.17)$ & $9.68(1.44)$ \\
\hline Thorichthys meeki & 3 & $42.00(2.00)$ & $-29.49(2.64)$ & $8.23(2.68)$ & 6 & 45.33 (7.99) & $-29.11(1.95)$ & $7.75(1.00)$ \\
\hline Thorichthys pasionis & 1 & 43.00 & -31.28 & 7.38 & 3 & $52.00(3.00)$ & $-29.07(0.39)$ & $7.17(0.41)$ \\
\hline Thorichthys pasionis & & & & & 3 & $100.67(1.53)$ & $-27.76(0.20)$ & $8.30(0.42)$ \\
\hline Thorichthys socolofi & 3 & $76.67(1.53)$ & $-30.21(0.58)$ & $5.98(0.50)$ & 2 & $79.00(14.14)$ & $-27.53(2.67)$ & $8.37(1.76)$ \\
\hline Trinectes maculatus & & & & & 2 & $51.00(4.24)$ & $-27.95(1.42)$ & $9.42(1.17)$ \\
\hline Vieja heterospila & 4 & $120.75(0.50)$ & $-27.09(3.55)$ & $7.70(2.85)$ & & & & \\
\hline Vieja synspila & 1 & 56.00 & -31.07 & 5.23 & 3 & $53.67(7.23)$ & $-26.51(3.35)$ & $6.83(1.34)$ \\
\hline Vieja synspila & 2 & $94.00(18.38)$ & $-27.33(0.76)$ & $8.28(0.20)$ & & & & \\
\hline \multicolumn{9}{|l|}{ Crustaceans/Mollusks } \\
\hline Aratus pisoni & 3 & $26.00(2.65)$ & $-25.62(0.48)$ & $4.22(0.41)$ & & & & \\
\hline Callinectes rathbunae & & & & & $6^{* *}$ & $42.00(3.46)$ & $-27.75(0.98)$ & $9.67(2.89)$ \\
\hline Callinectes rathbunae & & & & & 3 & $118.00(7.21)$ & $-27.56(2.67)$ & $8.14(0.82)$ \\
\hline Goniopsis cruentata & 3 & $33.67(3.21)$ & $-24.22(2.33)$ & $5.94(0.81)$ & & & & \\
\hline Macrobrachium acanthurus & & & & & 6 & $70.50(18.09)$ & $-26.62(0.50)$ & $8.26(0.33)$ \\
\hline Lampsilis tampicoensis & & & & & 3 & $96.33(4.04)$ & $-32.36(0.42)$ & $6.37(0.07)$ \\
\hline Neritina reclivata & & & & & $15^{*}$ & $10.77(1.01)$ & -26.77 & 7.84 \\
\hline Polymesoda arctata & & & & & 3 & $60.33(5.03)$ & $-32.65(0.40)$ & $5.87(0.18)$ \\
\hline Pomacea flagellata & & & & & 1 & 71.00 & -27.33 & 3.75 \\
\hline Uca rapax & $14^{* * * *}$ & $23.07(3.43)$ & $-27.99(0.83)$ & $8.32(1.32)$ & & & & \\
\hline \multicolumn{9}{|l|}{ Plants/Algae } \\
\hline Avicennia germinans & 2 & & $-29.91(1.90)$ & $3.07(0.85)$ & & & & \\
\hline Bucida buceras & 3 & & $-28.54(3.23)$ & $5.10(1.44)$ & & & & \\
\hline Crinum americanum & 4 & & $-30.16(1.97)$ & $5.51(2.46)$ & & & & \\
\hline Eichornia crassipes & 3 & & $-27.77(1.67)$ & $8.43(2.85)$ & 3 & & $-28.21(0.10)$ & $6.33(0.52)$ \\
\hline Epiphytic algae on wood & & & & & 2 & & $-25.58(5.29)$ & $4.97(5.24)$ \\
\hline Epiphytic algae on $V$. americana & & & & & 1 & & -10.64 & 4.08 \\
\hline Laguncularia racemosa & 3 & & $-28.39(1.16)$ & $8.10(3.54)$ & & & & \\
\hline Lonchocarpus hondurensis & 4 & & $-26.29(5.08)$ & $4.56(3.69)$ & & & & \\
\hline Phragmites australis & & & & & 3 & & $-28.57(1.50)$ & $5.13(1.06)$ \\
\hline Rizophora mangle & 3 & & $-29.82(2.53)$ & $4.44(4.42)$ & & & & \\
\hline Salvinia rotundifolia & & & & & 3 & & $-27.99(0.32)$ & $7.67(2.95)$ \\
\hline Thalia geniculata & & & & & 2 & & $-26.92(0.32)$ & $7.92(0.20)$ \\
\hline Typa latifolia & & & & & 2 & & $-28.92(0.33)$ & $7.28(1.87)$ \\
\hline Vallisneria americana & & & & & 3 & & $-21.53(5.42)$ & $1.62(1.37)$ \\
\hline Flocculated detritus & & & & & 1 & & -26.77 & 2.07 \\
\hline
\end{tabular}


Epiphytic algae on eelgrass was the most ${ }^{13} \mathrm{C}$-enriched carbon source collected in either habitat (-10.64\%). American eelgrass was the second most ${ }^{13} \mathrm{C}$-enriched carbon source (-21.53\%), although its signature was quite variable (Table 1). Vallisneria americana and flocculated detritus had the most depleted $\delta^{15} \mathrm{~N}$ values observed for all primary producers (Table 1, Fig. 2 ). At the community level, both primary producers and aquatic consumers were slightly more ${ }^{13} \mathrm{C}$-depleted at Polo Stream than in San Pedrito Lagoon (Fig. 2).

A total of 39 consumer taxa ( 30 fish species, 9 species of crustaceans and mollusks) were collected at the two sites, with greater diversity of fishes and invertebrates at San Pedrito Lagoon (Table 1). Most consumers at both sites had carbon stable isotope signatures between -33 and $-25 \%$ (Table 1 , Fig. 2). At Polo Stream, these values align with $\delta^{13} \mathrm{C}$ values observed for all primary producers collected, including all mangrove species (Fig. 2). One exception was juvenile Flathead mullet Mugil cephalus that had a carbon isotope signature greatly enriched compared with all other consumer and primary producer taxa (Table 1, Fig. 2). Consumers at San Pedrito Lagoon had carbon isotope signatures that were most similar to riparian sources of production and flocculated organic material (Table 1, Fig. 2). Although almost all consumers were ${ }^{13} \mathrm{C}$-depleted compared with the mean value of American eelgrass (Fig. 2), the wide variability in $\delta^{13} \mathrm{C}$ values for $V$. americana prevent it from being excluded as a potential carbon source to consumers. The Grass carp Ctenopharyngodon idella had the most ${ }^{13} \mathrm{C}$-enriched signature at San Pedrito Lagoon, similar to that of American eelgrass (Table 1, Fig. 2).

Combined with the $\delta^{13} \mathrm{C}$ data, nitrogen isotope signatures of primary producers and consumers allow us to refine estimates of relative importance of basal sources to aquatic consumers. For example, the comparatively ${ }^{15} \mathrm{~N}$-enriched values observed for White mangrove and Water hyacinth indicate that they are unlikely to be important sources of carbon to the Polo Stream food web because the 2.5-3.4\%o per trophic level fractionation of $\delta^{15} \mathrm{~N}$ would exceed nitrogen isotope values of primary consumers (Fig. 2).

Observed values for the other mangrove species, especially the Red mangrove, indicate they are likely important carbon sources for aquatic consumers. At San Pedrito Lagoon, the depleted $\delta^{15} \mathrm{~N}$ values for American eelgrass and flocculated detritus indicate that only the snail Pomacea flagellata and maybe the omnivorous catfish Rhamdia quelen likely feed directly on these abundant carbon sources (Fig. 2). Combined carbon and nitrogen isotope signatures of the dominant littoral vegetation, mainly Phragmites australis, suggest that aquatic food web of San Pedrito Lagoon may rely to a greater degree on these carbon sources even though submerged aquatic vegetation is ubiquitous (Table 1, Fig. 2).

Based on fractionation of $\delta^{15} \mathrm{~N}$ values per trophic transfer, both food webs have approximately three to four trophic levels (Fig. 2). The top predator in the Polo Stream food web was the Tropical gar Atractosteus tropicus, a valuable fisheries species. Also with high $\delta^{15} \mathrm{~N}$ values in Polo Stream were the diadromous Bay anchovy Anchoa mitchilli and Flathead mullet (Table 1). Carbon and nitrogen isotope values for Flathead mullet suggest that they had very recently recruited into the stream from the coastal zone. Highest consumer $\delta^{15} \mathrm{~N}$ values observed in San Pedrito Lagoon were for the invertivorous Opossum pipefish Microphis brachyurus lineatus, Striped mojarra Eugerres plumieri and Yellow cichlid Thorichthys helleri (Table 1).
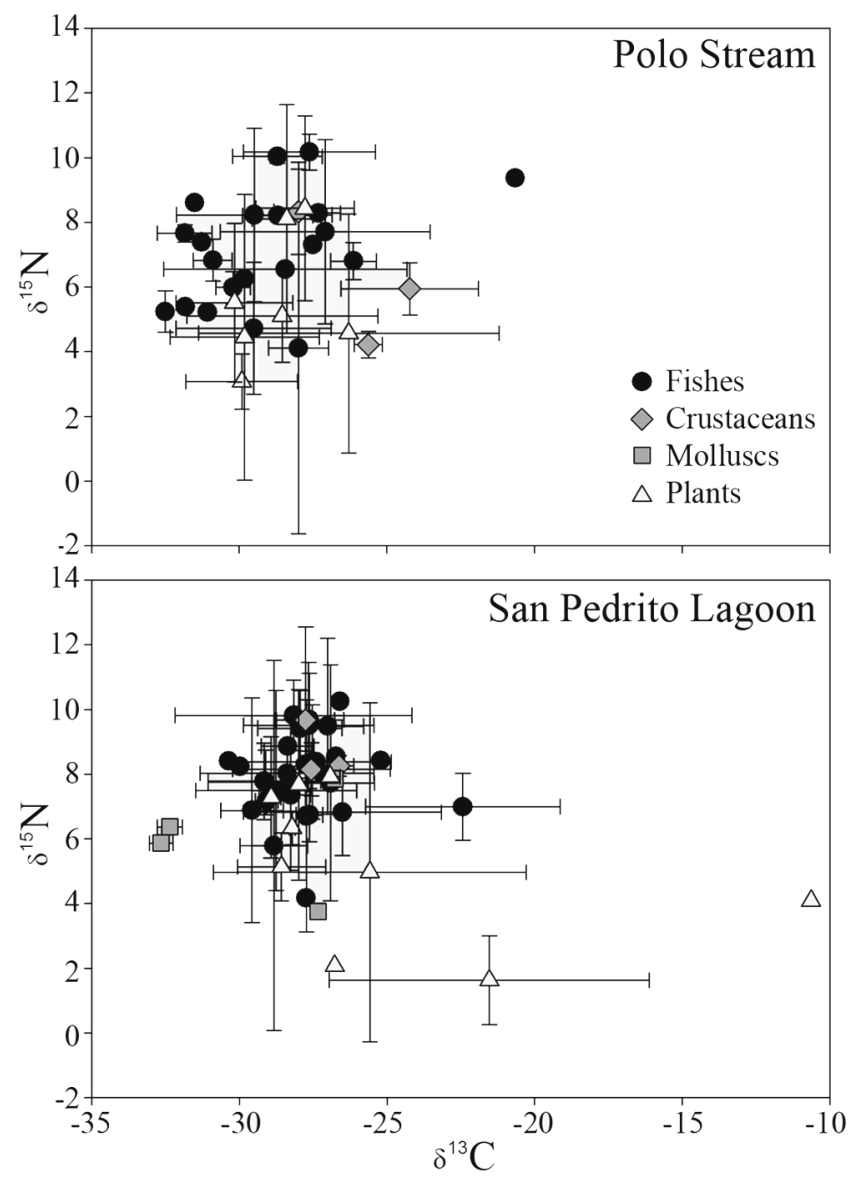

Fig. 2. Mean $( \pm$ S.D. $) \delta^{13} \mathrm{C}$ and $\delta^{15} \mathrm{~N}$ values of consumers (fishes, crustaceans and mollusks) and primary producers in Polo Stream and San Pedrito Lagoon. Species identities are in Table 1.

\section{Discussion}

Mangroves and submerged aquatic vegetation are ecologically important habitats at various stages during the life-cycles of many marine, estuarine and freshwater fishes (Shih-Rong et al., 1999; Rozas \& Minello, 2006; Saintilan et al., 2007; Shervette et al., 2007). The importance of these habitats was reflected in the high diversity of fishes collected in Polo Stream and San Pedrito Lagoon in the CWBR. Freshwater conditions were dominant during our survey periods (and are fairly stable on an annual basis), and freshwater fishes comprised the majority ( $80 \%$ ) of species collected. Diadromous species made up the remaining 20\%, including Anchoa mitchilli, 
Centropomus undecimalis, Diapterus auratus, Eugerres plumieri, Mugil cephalus and Strogylura marina.

Aquatic food webs of Polo Stream and San Pedrito Lagoon both appear to utilize locally derived sources of primary production as principal carbon sources. Carbon and nitrogen stable isotope ratios of aquatic consumers in Polo Stream indicated that mangrove-derived carbon (likely in the form of detritus) is the most important carbon source for the food web. Although all mangrove species had similar carbon isotope ratios, nitrogen isotope ratios were useful to refine the potential contributions and the dominant Red mangrove is likely the most important carbon source for the aquatic food web. This finding is contrary to two recent studies from mangrove creeks in Australia (Abrantes \& Sheaves, 2009) and Africa (Nyunja et al., 2009) that found mangrove-derived carbon to be of limited importance for fishes. In both of these studies, mangrove creeks were adjacent to seagrass beds, and seagrasses and epiphytes were the dominant sources supporting secondary production. Mangrove-derived carbon appears to be important to aquatic food webs when comparatively more labile carbon sources such as seagrass and epiphytes are not readily accessible (e.g. as in our study system).

In San Pedrito Lagoon, multiple carbon sources appear to support the food web. Although American eelgrass forms dense mats that dominate large portions of the lagoon, carbon derived from this ubiquitous resource appears to be utilized in combination with carbon derived from riparian grasses such as Common reed. However, interpretations of carbon source importance in San Pedrito Lagoon may be slightly affected by variation in carbon and nitrogen isotope signatures in our samples of American eelgrass $\left(\delta^{13} \mathrm{C}:-27.80\right.$ to $-18.23 \%$, $\delta^{15} \mathrm{~N}$ : 0.08 to $2.70 \%$ ). This variation may reflect residual epiphytic algae that we were unable to remove during processing, or spatial variation in $\delta^{13} \mathrm{C}$ of dissolved inorganic carbon (DIC) used as a substrate for photosynthesis. Addition of epiphytic algae $\left(\delta^{13} \mathrm{C}:-10.64 \%\right.$ o, $\delta^{15} \mathrm{~N}: 4.08 \%$ ) to the most depleted sample of American eelgrass $\left(\delta^{13} \mathrm{C}:-27.80 \%, \delta^{15} \mathrm{~N}\right.$ : $0.08 \%$; similar to $\delta^{13} \mathrm{C}$ values observed by Chanton \& Lewis, 2002) could yield the more enriched carbon and nitrogen signatures observed for the other samples of eelgrass $\left(\delta^{13} \mathrm{C}:-18.23\right.$ and $-18.58 \%$, $\delta^{15} \mathrm{~N}: 2.70$ and $2.09 \%$ ). Alternatively, depleted $\delta^{13} \mathrm{C}$ values for eelgrass may be expected near the connection with the Usumacinta River, and enriched values expected in the middle of dense eelgrass mats due to ${ }^{13} \mathrm{C}$-enrichment of the residual DIC pool through preferential fixation of ${ }^{12} \mathrm{C}$ during photosynthesis (Bouillon et al., 2008). In either case, the depleted nitrogen isotope ratio of eelgrass still prevents it from being a predominant carbon source for the majority of aquatic consumer taxa collected during our survey. Furthermore, consumers likely feed at a variety of locations in the lagoon (minimizing any effects of spatial variability in the DIC pool), and may consume the combined material from eelgrass and its epiphytic algae together (either as detritus or in its live form such as by herbivorous Grass carp).

Terrestrial insects (not collected in this study) likely are the link between riparian production sources and aquatic consumers at San Pedrito Lagoon. Terrestrial insects should have comparatively higher $\delta^{15} \mathrm{~N}$ values than their aquatic counterparts due to the approximately $3 \%$ difference in $\delta^{15} \mathrm{~N}$ of riparian and aquatic carbon sources. Therefore, the large variation in $\delta^{15} \mathrm{~N}$ values for the invertivorous fish species that dominated the San Pedrito Lagoon food web could be due to consuming different proportions of terrestrial and aquatic insects. Wantzen et al. (2002) observed a comparable amount of variation in $\delta^{15} \mathrm{~N}$ values of invertivorous fish species in the Pantanal, and suggested that such variation may be due to differences in consumption of aquatic and terrestrial resources, especially as influenced by seasonal flooding. Zeug \& Winemiller (2008) found riparian vegetation to be the dominant carbon source utilized in food webs of a temperate floodplain river system, with invertebrates as the pathway by which riparian-derived carbon entered the aquatic food web. Future research in CWBR should examine the role played by terrestrial insects as a mechanism linking riparian and aquatic food webs.

Our cursory evaluation of vertical trophic structure suggested that both the stream and lagoon food webs had approximately three to four trophic levels. However, our preliminary data did not allow us to examine fine-scale variation in food-chain length that typifies most aquatic ecosystems (e.g. Vander Zanden \& Fetzer, 2007; Hoeinghaus et al., 2008). For example, Vander Zanden \& Fetzer (2007) conducted a global literature synthesis of aquatic food-chain length and found stream food-chains to be approximately 0.5 trophic levels shorter on average than those in lake and marine ecosystems. Similarly, Hoeinghaus et al. (2008) found foodchain lengths of four aquatic landscape types of the upper Paraná River basin, Brazil, to differ by approximately 0.35 trophic levels. Small differences in food-chain length between our stream and lagoon food webs may therefore be expected. Even small differences in food-chain length may result in large differences in the amount of energy required to support upper trophic-level consumers due to low energetic assimilation efficiency of trophic interactions $(10 \%$ on average; Humphreys, 1979). Small differences in trophic position can therefore have important natural resource management and conservation implications, such as for fisheries sustainability (e.g. Hoeinghaus et al., 2009).

One issue of special concern to this ecosystem is the introduced Amazon sailfin catfish Pterygoplichthys pardalis. This herbivorous/detritivorous species and its congeners are typical components of freshwater communities throughout much of South America (Armbruster \& Page, 2006). Pterygoplichthys pardalis was introduced in Mexico through the commercial aquarium trade and is quickly spreading in southeastern Mexico (Wakida-Kusunoki et al., 2007). Since 2002 , P. pardalis is very abundant in artisanal fisheries catches within CWBR (Mendoza-Carranza et al., 2008). Several native fish species with high commercial importance (A.tropicus, $C$. undecimalis, Parachromis managuensis, Petenia splendida, Cichlasoma urophthalmum, Vieja heterospila, V. synspila, Gobiomorus dormitor) co-occurr with the introduced Amazon sailfin catfish and have similar carbon isotope signatures. This 
spatial and isotopic overlap suggests the possibility of competition for resources. Ecological and fisheries implications of the introduction and expansion of $P$. pardalis in CWBR and freshwater ecosystems of Tabasco require urgent attention.

Mangrove and seagrass habitats are conspicuous components of the CWBR landscape; however, the ecology of these habitats is poorly understood. Our results indicate that aquatic food webs of CWBR are based primarily on locally abundant riparian production sources during our study period. Future studies during different seasons should validate these trends. Jointly with other studies in CWBR, these findings can be used as a baseline to reinforce the conservation and management of this important reserve. Diverse external and internal human activities (e.g. species introductions, overfishing, pollution, and habitat alteration associated with oil extraction and agriculture) threaten the sustainability of CWBR, and additional research examining the ecology and functioning of this spatially and temporally complex wetland ecosystem is critical for its conservation.

\section{Acknowledgements}

The authors thank Candelario Jimenez, Edith Ramirez, Benjamin Martinez (Mincho) and Gustavo Salvador Guzman for help during sampling surveys. Thanks to Alejandra Sepulveda and Allison Pease for an early revision. This research was sponsored by CONACYT. This research was sponsored partially by CONACYT and International Foundation for Science (IFS).

\section{Literature Cited}

Abrantes, K. \& M. Sheaves. 2009. Food web structure in a nearpristine mangrove area of the Australian Wet Tropics. Estuarine, Coastal and Shelf Science, 82(4): 597-607.

Armbruster J. W. \& L. M. Page. 2006. Redescription of Pterygoplichthys punctatus and description of a new species of Pterygoplichthys (Siluriformes: Loricaridae). Neotropical Ichthyology, 4(4): 401-409.

Arriaga C. L., E. D. Vázquez, J. C. González, R. R. Jiménez, E. L. Muñoz \& V. S. Aguilar. 1998. Regiones marinas prioritarias de México. México, Comisión Nacional para el Conocimiento y uso de la Biodiversidad, 198p.

Bouillon, S., R. M. Connolly \& S. Y. Lee. 2008. Organic matter exchange and cycling in mangrove ecosystems: Recent insights from stable isotope studies. Journal of Sea Research, 59: 44-58.

Bouillon, S., A. V. Raman, P. Dauby \& F. Dehairs. 2002. Carbon and nitrogen stable isotope ratios of subtidal benthic invertebrates in an estuarine mangrove ecosystem (Andhra Pradesh, India). Estuarine, Coastal and Shelf Science, 54(5): 901-913.

Chanton, J. \& F. G. Lewis. 2002. Examination of coupling between primary and secondary production in a river-dominated estuary: Apalachicola Bay, Florida, U.S.A. Limnology and Oceanography, 47(3): 683-697.

Garcia, A. M., D. J. Hoeinghaus, J. P. Vieira \& K. O. Winemiller. 2007. Isotopic variation of fishes in freshwater and estuarine zones of a large subtropical coastal lagoon. Estuarine Coastal and Shelf Science, 73(3-4): 399-408.
Heck, K. L. Jr., C. Hays \& R. J. Orth. 2003. A critical review of the nursery role hypothesis for seagrass meadows. Marine Ecology Progress Series, 253: 123-136.

Hoeinghaus, D. J., A. A. Agostinho, L. C. Gomes, F. M. Pelicice, E. K. Okada, J. D. Latini, E. A. L. Kashiwaqui \& K. O. Winemiller. 2009. Effects of river impoundment on ecosystem services of large tropical rivers: Embodied energy and market value of artisanal fisheries. Conservation Biology, 23: 1222-1231.

Hoeinghaus, D. J. \& S. E. Davis. 2007. Size-based trophic shifts of saltmarsh dwelling blue crabs elucidated by dual stable $\mathrm{C}$ and $\mathrm{N}$ isotope analyses. Marine Ecology Progress Series, 334: 199-204.

Hoeinghaus, D. J., K. O. Winemiller \& A. A. Agostinho. 2007. Landscape-scale hydrologic characteristics differentiate patterns of carbon flow in large-river food webs. Ecosystems, 10: 10191033.

Hoeinghaus, D. J., K. O. Winemiller \& A. A. Agostinho. 2008. Hydrogeomorphology and river impoundment affect food-chain length of diverse Neotropical food webs. Oikos, 117: 984-995.

Hogarth, P. 2007. The biology of mangroves and seagrasses. New York, Oxford University press, 273p.

Humphreys, W. F. 1979. Production and respiration in animal populations. Journal of Animal Ecology, 48: 427-453.

INE. 2000. Programa de Manejo de la Reserva de la Biosfera Pantanos de Centla. México, Instituto Nacional de Ecología, 222p.

McCutchan, J. H. Jr., W. M. Lewis, C. Kendall \& C. C. McGrath. 2003. Variation in trophic shift for stable isotope ratios of carbon, nitrogen and sulfur. Oikos, 102: 378-390.

Melville, A. J. \& R. M. Connolly. 2003. Spatial analysis of stable isotope data to determine primary sources of nutrition for fish. Oecologia, 136: 499-507.

Mendoza-Carranza, M., M. L. Martínez-Gutiérrez, E. C. SeguraBerttolini, A. Romero-Rodríguez \& A. Hernández-López. 2008. Memorias del taller diagnóstico de la pesca en la Reserva de la Biosfera Pantanos de Centla "La perspectiva social de pesca en los Pantanos de Centla”. San Cristobal de las Casas, México, Ecosur Editores, 96p.

Moore, K. A. 2004. Influence of seagrasses on water quality in shallow regions of the lower Chesapeake Bay. Journal of Coastal Research, 81: 162-178.

Nagelkerken, I. \& G. van der Velde. 2004a. Are Caribbean mangroves important feeding grounds for juvenile reef fish from adjacent seagrass beds? Marine Ecology Progress Series, 274: 143-151.

Nagelkerken, I. \& G. van der Velde. 2004b. Relative importance of interlinked mangroves and seagrass beds as feeding habitats for juvenile reef fish on a Caribbean island. Marine Ecology Progress Series, 274: 153-159.

Nichols, P. D., D. W. Klumpp \& R. B. Johns. 1985. A study of food chains in seagrass communities III. Stable carbon isotope ratios. Australian Journal of Marine and Freshwater Research, 36(5): 683-690.

Novelo, R. A. 2006. Plantas acuáticas de la Reserva de la Biosfera Pantanos de Centla. Mexico, Comisión Nacional para el Conocimiento y Uso de la Biodiversidad Espacios Naturales y Desarrollo Sustentable, 254p.

Nyunja, J., M. Ntiba, J. Onyari, K. Mavuti, K. Soetaert \& S. Bouillon. 2009. Carbon sources supporting a diverse fish community in a tropical coastal ecosystem (Gazi Bay, Kenya). Estuarine, Coastal and Shelf Science, 83: 333-341.

Peterson, B. J. \& B. Fry. 1987. Stable isotopes in ecosystem studies. Annual Review of Ecology Evolution and Systematics, 18: 293-320. 
Post, D. M. 2002. Using stable isotopes to estimate trophic position: models, methods and assumptions. Ecology, 83: 703-718.

Richardson, W. B., S. J. Zigler \& M. R. Dewey. 1998. Bioenergetic relations in submerged aquatic vegetation: an experimental test of prey use by juvenile bluegills. Ecology of Freshwater Fishes, 7: 1-12.

Rodelli, M. R., J. N. Gearing, P. J. Gearing, N. Marshall \& A. Sasekumar. 1984. Stable isotope ratio as a tracer of mangrove carbon in Malaysian ecosystems. Oecologia, 61: 326-333.

Rozas, L. P. \& T. J. Minello. 2006. Nekton use of Vallisneria americana Michx (Wild Celery) beds and adjacent habitats in coastal Louisiana. Estuaries and Coasts, 29: 297-310.

Saintilan, N., K. Hossain \& D. Mazumder. 2007. Linkages between seagrass, mangrove and saltmarsh as fish habitat in the Botany Bay estuary, New South Wales. Wetlands Ecology and Management, 15: 277-286.

Sheridan, P. \& C. Hays. 2003. Are mangroves nursery habitat for transient fishes and decapods? Wetlands, 23: 449-458.

Shervette, V. R., W. E. Aguirre, E. Blacio, R. Cevallos, M. González, F. Pozo \& F. Gelwick. 2007. Fish communities of a disturbed mangrove wetland and an adjacent tidal river in Palmar, Ecuador. Estuarine, Coastal and Shelf Science, 72: 115-128.

Shih-Rong, K., L. Hsing-Juh \& S. Kwnag-Tsao. 1999. Fish assemblages in the mangrove creeks of northern and southern Taiwan. Estuaries, 22: 1004-1015.

Sobrado, M. A. 1999. Drought effects on photosynthesis of the mangrove, Avicennia germinans, under hypersaline conditions. Trees Structure and Function, 13(3): 125-130.

Sobrado, M. A. \& M. C. Ball. 1999. Light use in relation to carbon gain in the mangrove, Avicennia marina, under hypersaline conditions. Australian Journal of Plant Physiology, 26(3): 245-251.

Thayer, G. W., D. A. Wolfe \& R. B. Williams. 1975. The impact of man on seagrass systems. American Scientist, 63: 288-296.

Vander Zanden, M. J. \& W. W. Fetzer. 2007. Global patterns of aquatic food chain length. Oikos, 116: 1378-1388.

Vanderklift, M.A. \& S. Ponsard. 2003. Sources of variation in consumer$\operatorname{diet} \delta 15 \mathrm{~N}$ enrichment: a meta-analysis. Oecologia, 136: 169-182.

Vermaat, J. E., L. Santamaria \& P. J. Roos. 2000. Water flow across and sediment trapping in submerged macrophyte beds of contrasting growth form. Archiv für Hydrobiologie, 148: 549-562.

Wakida-Kusunoki, A. T., R. Ruiz-Carus \& E. Amador-del-Angel. 2007. Amazon sailfin catfish, Pterygoplichthys pardalis (Castelnau, 1855) (Loricariidae), another exotic species established in southeastern Mexico. The Southwestern Naturalist, 52: 141-144.

Wantzen, K. M., F. de A. Machado, M. Voss, H. Boriss \& W. J. Junk. 2002. Seasonal isotopic shifts in fish of the Pantanal wetland, Brazil. Aquatic Sciences, 64: 239-251.

Yáñez-Arancibia, A. \& P. Sánchez-Gil. 1988. Caracterización ambiental de la Sonda de Campeche frente a la Laguna de Términos. Pp. 41-50. In: Yañez-Arancibia, A. \& J. W. Day, Jr. (Eds.). Ecología de los ecosistemas costeros del sur del Golfo de México: La región de la Laguna de Términos. Instituto de Ciencias del Mar y Limnología. Universidad Nacional Autónoma de México. Coastal Ecology Institute, Louisiana State University. México, Editorial Universitaria.

Zeug, S. C. \& K. O. Winemiller. 2008. Evidence supporting the importance of terrestrial carbon in a large-river food web. Ecology, 89: 1733-1743. 